\title{
RESISTIVE INDEX OF INTERNAL CAROTID ARTERY AND BRAIN NETWORKS IN PATIENTS WITH CHRONIC CEREBRAL ISCHEMIA
}

Fokin VF $\bowtie$, Ponomareva NV, Medvedev RB, Konovalov RN, Krotenkova MV, Lagoda OV, Tanashyan MM

Research Center of Neurology, Moscow, Russia

Quantitative assessment of cerebral hemodynamics is important for patients with chronic cerebral ischemia (CCl), as it helps to reveal the pathogenesis of the disease and set the course for effective prevention and treatment. The study was aimed to assess the correlation of the left carotid artery (ICA) resistive index (RI) with cognitive functions and brain network organization based on fMRI data in patients with CCI (51 males and 105 females). The listed above indicators were studied in patients with the left ICA RI values below and above the average $(0.54 \pm 0.013)$. The lower, normal physiological ICA resistance levels corresponded to the more successful realization of verbal cognitive functions. In the first group, $\mathrm{RI}$ was within normal range $(\mathrm{Rl}=0.42 \pm 0.007)$, and in the second group $\mathrm{Rl}$ exceeded normal levels $(R I=0.61 \pm 0.01)$. Variation of the right ICA RI did not correlate with the characteristics of verbal cognitive functions. FMRI data analysis was used to assess the differences in connectivity between various brain regions in the groups with low and high RI. The normal physiological and elevated RI values of the left ICA correlated with differences in the organization of brain networks: normal physiological RI values corresponded to a better organization of hemispheric connections in the basal ganglia and brainstem, and high RI values corresponded to a better organization of connections between the frontal regions and the cerebellum as well as occipital areas of the cerebral cortex. The left ICA RI can be considered as a biomarker of cognitive decline and brain networks reorganization in patients with CCI.

Keywords: chronic cerebral ischemia, internal carotid artery, resistive index, cognitive functions, neural networks

Author contribution: Fokin VF — study concept, manuscript writing; Ponomareva NV — statistical analysis, manuscript writing; Medvedev RB — duplex ultrasonography, hemodynamic data analysis; Konovalov RN — fMRI data acquisition and analysis; Krotenkova MV — fMRI data analysis, study design; Lagoda OV — clinical data analysis; Tanashyan MM — clinical data analysis, study design.

Compliance with ethical standards: the study was approved by the Ethics Committee of the Research Center of Neurology (protocol № 11/14 dated November 19, 2014); the informed consent was submitted by all patients.

$\triangle$ Correspondence should be addressed: Vitaly F. Fokin

Volokolamskoye shosse, 80, Moscow, 125367; fvf@mail.ru

Received: 27.10.2021 Accepted: 15.11.2021 Published online: 27.11.2021

DOI: $10.24075 / \mathrm{brsmu} .2021 .055$

\section{ИНДЕКС РЕЗИСТЕНТНОСТИ ВНУТРЕННИХ СОННЫХ АРТЕРИЙ И НЕЙРОСЕТИ МОЗГА ПРИ ХРОНИЧЕСКОЙ ЦЕРЕБРАЛЬНОЙ ИШЕМИИ}

В. Ф. Фокин ${ }$, Н. В. Пономарева, Р. Б. Медведев, Р. Н. Коновалов, М. В. Кротенкова, О. В. Лагода, М. М. Танашян

Научный центр неврологии, Москва, Россия

Изучение количественных показателей церебральной гемодинамики актуально для больных хронической ишемией мозга (ХИМ), поскольку оно помогает раскрыть патогенез этого заболевания, а также определить направления его эффективной диагностики и лечения. Целью работы было оценить сопряженность индекса резистентности (RI) левой внутренней сонной артерии (BCA) с когнитивными функциями и организацией церебральных нейросетей по данным фМРТ у больных ХИМ (51 мужчина и 105 женщин). Указанные показатели исследовали при значениях RI левой ВСА ниже и выше среднего уровня (0,54 \pm 0,013). Более низкий, физиологически нормальный уровень резистентности левой ВСА соответствовал более успешному выполнению когнитивных вербальных функций. В первой группе RI находился в пределах физиологической нормы (RI = 0,42 \pm 0,007), тогда как во второй RI был выше нормальных значений $(\mathrm{Rl}=0,61 \pm$ 0,01). Вариация RI правой BCA не была взаимосвязана с характеристиками вербальных функций. Посредством анализа фМРТ определяли разность показателей коннективности между различными областями мозга в группах с низким и высоким RI. Физиологически нормальный и повышенный RI левой BCA сопряжены с различиями в организации нейросетей: при физиологически нормальном RI лучше выражены межполушарные коммуникации на уровне базальных ганглиев и ствола мозга, а при высоком - связи, соединяющие лобные области с мозжечком и затылочными областями коры. RI левой BCA можно рассматривать как биомаркер когнитивного снижения и реорганизации нейронных сетей у больных ХИМ.

Ключевые слова: хроническая ишемия мозга, внутренняя сонная артерия, индекс резистентности, когнитивные функции, нейросети

Вклад авторов: В. Ф. Фокин - концепция исследования, написание статьи; Н. В. Пономарева - статистический анализ, написание статьи; Р. Б. Медведев - дуплексное сканирование; анализ гемодинамических данных; Р. Н. Коновалов - регистрация и анализ фМРТ; М. В. Кротенкова анализ фМРТ, дизайн исследования; О. В. Лагода - клинический анализ; М. М. Танашян - клинический анализ, дизайн исследования.

Соблюдение этических стандартов: исследование одобрено этическим комитетом Научного центра неврологии (протокол № $11 / 14$ от 19 ноября 2014 г.); все участники подписали информированное согласие на участие в исследовании.

$\checkmark$ Для корреспонденции: Виталий Федорович Фокин Волоколамское шоссе, д. 80, г. Москва, 125367; fvf@mail.ru

Статья получена: 27.10.2021 Статья принята к печати: 15.11.2021 Опубликована онлайн: 27.11.2021

DOI: $10.24075 /$ vrgmu.2021.055

Chronic cerebral ischemia (CCl) is among prevalent socially significant vascular diseases [1]. Maintaining the normal levels of cerebral circulation is a major challenge for patients with $\mathrm{CCl}$. In this regard, the internal carotid artery (ICA) blood flow plays a vital part in maintaining the normal function of the brain. There are numerous papers, which demonstrate that impaired cerebral circulation through ICA results in hypoxia, structural and functional changes in the basin of ICA, and cognitive impairment, especially in case of impaired left ICA blood flow, since the left hemisphere is involved in organization and regulation of many cognitive functions in right-handed individuals [2]. There is a number of cerebral blood flow indicators, commonly used to characterize circulation: linear blood flow velocity and volumetric blood flow rate, resistive index $(\mathrm{RI})$, etc. $\mathrm{Rl}$ has been used in our study, since this is a composite indicator being the difference between the systolic 
and diastolic blood velocities divided by the systolic velocity. Along with the intima-media complex thickness, this indicator is used to describe cerebral arteriosclerosis. RI shows an upward trend with the progress of $\mathrm{CCl}$ and small vessel diseases [3].

Another aspect just as important in this problem pertains to the question of which neurophysiological mechanisms the increased ICA RI values are related to. Currently, the concept of "brain networks" is widely used, significantly owing its development to the success of functional MRI (fMRI). The concept of connectivity, i.e. the synchronized changes of blood oxygen level-dependent (BOLD) signal, which, according to many researchers, indicate the involvement of these regions in the joint functional system, is the key concept in brain network research. The BOLD signal changes reflect the transition of hemoglobin, contained in red blood cells, from oxidized to reduced form in various brain structures. Temporal correlations of low-frequency BOLD signal fluctuations in various brain regions reveal the organized functional brain networks. Connectivity, derived from resting state $\mathrm{fMRI}$ data, provides the means to describe and investigate intercentral relationships, it is considered a potential biomarker of neurological and mental disorders $[4,5]$.

Depicturing of neural networks made it possible to better understand the dynamics of nerve centers in cerebrovascular disorders leading to neuron dysfunction and their death.

With the development of chronic disorders of cerebral circulation, the cortical nerve centers and other structures of the brain are disproportionately affected, which leads to the emergence of a new neural organization. Thus, according to the authors of [6], the volume of the hippocampus, thalamus, putamen, angular gyrus and other structures depends on the level of oxygen saturation in the blood, but the structures listed above differ in their sensitivity to hypoxia. In addition, the density of neurons varies in different areas of the brain, and the density of capillaries is much more uniform [7]. Therefore, it can be assumed that increased arterial stiffness due to atherosclerosis, reflected in an increase in $\mathrm{Rl}$ and accompanied by hemodynamic disorders, will affect the reorganization of the brain network due to hypoxia occurring in the most vulnerable areas of the brain [8]. This determines the relevance of studying $\mathrm{Rl}$ in order to solve a whole range of problems related to the $\mathrm{CCl}$. Two of these problems are the most significant: the correlation of the above indicator with cognitive functions and the relationship between $\mathrm{Rl}$ and brain networks.

The study was aimed to assess the correlation of ICA RI with cognitive decline and the indicators of the resting-state networks in patients with $\mathrm{CCl}$.

\section{METHODS}

The study was carried out in 2019-2021 at the Research Center of Neurology. A total of 156 patients with $\mathrm{CCl}(51$ males and 105 females) aged $51-85$ (the average age was $67.0 \pm 0.69$ years, SD 8.74) were enrolled. Cognitive impairment is observed in patients with $\mathrm{CCl}$, the patients differ mainly in quantitative characteristics of memory impairment, performance, irritability,

Table 1. Correlation between right and left ICA RI values and cognitive functions brainstem symptoms, etc. The main etiological causes of $\mathrm{CCl}$ in the patients examined were as follows: atherosclerosis, arterial hypertension (including the hypertension disease), venous insufficiency, etc. Arterial hypertension (stage 1 and stage 2 hypertension) was found in all patients. Patients with atherosclerotic plaque buildup in the ICA and ICA stenosis up to $60 \%$ were selected for the study.

Inclusion criteria: compliance with stage I or II dyscirculatory encephalopathy; patients, who did not need constant care in their daily life. The patients with stage I or II dyscirculatory encephalopathy differed mainly in quantitative characteristics of cognitive functions and had no history of acute cerebrovascular accidents. Exclusion criteria: dementia rated 1 or higher on the Clinical Dementia Rating Scale [9], the history of acute cerebrovascular accidents (all patients underwent MRI of the brain, in particular to exclude "silent" brain matter lesions, the diffusion-weighted imaging mode was used with a diffusionweighting factor $b=1000$ ), traumatic brain injuries, severe cardiac or metabolic (type 2 diabetes mellitus) decompensation, stages 3-5 of chronic kidney disease, uncompensated thyroid disease (hypothyroidism). All the subjects were right-handed. Contemporary ideas about the approaches to studying $\mathrm{CCl}$, as well as about dyscirculatory encephalopathy, are described in detail in a number of papers [10-12].

The psychometric assessment included Luria's verbal memory test [13], adapted for patients with this type of vascular disorder. We estimated the total number of words memorized by the patients after five repetitions of 10 words. After the test, we performed a sequential countdown (subtraction from 100 to 7 ) and evaluated the number of words memorized. The fluency test took into account the number of memorized words beginning with the letters S-, $\mathrm{K}$ - and $\mathrm{A}$-. Patients tried to name the maximum number of words (regular and proper nouns) beginning with the letters listed above, within one minute per letter. We estimated the overall (mean) scores on word recall and fluency stability based on the difference between the number of words memorized in the first and last letters. Patients also performed a letter recognition task based on the Kirschner n-back test (the subject found two identical letters next to each other in the free text without spaces), describing the ability to recognize letters non-verbally. pattern and concentration of attention [14].

Patients of both genders (20 males and 35 females) were subjected to $\mathrm{T}^{*}$-weighted resting-state $\mathrm{fMRI}$ in order to detect the BOLD signal using the MAGNETOM Verio 3T MRI system (Siemens; Germany). The subjects were offered the following instruction: to relax as much as possible, to lie still with their eyes closed in order to avoid stimulation of the visual sensory system, and not to think of anything special. Preprocessing of MRI data was performed using SPM12 software (Functional Imaging Laboratory at University College London; UK) in the MATLAB environment (MathWorks; USA). Connectivity was assessed using the CONN-18b application (McGovern Institute for Brain Research, Massachusetts Institute of Technology; USA) of the SPM-12 software toolbox [15].

\begin{tabular}{|l|c|c|}
\hline & Right ICA RI & Left ICA RI \\
\hline Recognition of nonverbal letter patterns & $-0.24 ; n=84 ; p=0.026$ & $-0.22 ; n=82 ; p=0.049$ \\
\hline Stability of verbal fluency & & $-0.26 ; n=67 ; p=0.035$ \\
\hline Immediate recall & & $-0.23 ; n=77 ; p=0.044$ \\
\hline Delayed recall & & \\
\hline
\end{tabular}

Note: $n$ - number of examined patients; $p$ - significance level, females; blank cells correspond to no significant correlation. 
Duplex ultrasonography was performed in all patients. Linear and volumetric systolic and diastolic blood flow velocities were assessed in the right and left ICA. Color-flow duplex ultrasonography was carried out using the Toshiba Viamo system (Toshiba; Japan). The nature and the values of linear and volumetric systolic blood flow velocities and RI of the arteries were studied using a generally accepted method with the linear probe $5.0-12.0 \mathrm{MHz}$. Rl was calculated as the difference between the systolic and diastolic blood flow velocities divided by the systolic blood flow velocity.

FMRI was used to assess brain network connectivity in 55 patients, being in a quiet waking state. Connectivity was compared between two groups of patients, which differed in $\mathrm{Rl}$. Connectivity between two brain structures is equal to the regression coefficient of BOLD signals in these structures. The differences in connectivity between groups with low and high $\mathrm{Rl}$ were assessed based on the standardized regression coefficients adjusted for multiple comparisons (false discovery rate, FDR) [15]. The average $\mathrm{Rl}$ values for both groups are provided in the Results section. This sample of patients $(n=55)$ was similar $(p>0.05)$ to the sample used for $\mathrm{Rl}$ assessment $(n=156)$ based on $\mathrm{RI}$ values and psychological test scores.

Connectivity was assessed using the Statistica-12 software package (StatSoft; USA) for analysis of variance and other methods of studying variation, together with SPM-12 and CONN-18b applications in the MATLAB environment. Connectivity and the differences in connectivity between groups were assessed using multiple testing corrections taking into account FDR. The differences were considered significant when $p<0.05$.

\section{RESULTS}

The right and left ICA RI values were not significantly different, these were $0.564 \pm 0.011$ and $0.548 \pm 0.013$ respectively. There were no significant differences in $\mathrm{Rl}$ between the right and the left ICA in males and females (significance level for males $p=0.96$, significance level for females $p=0.21$ ). The right and left ICA RI values correlate with each other, and the correlation coefficient is significant with a very high significance level $(r=0.69 ; n=154 ; p<0.000001)$, that is why bilateral differences depend little on $\mathrm{RI}$ values, which may vary in different disease stages.

Studying the correlation of the right and the left ICA RI values with cognitive functions has shown that the main correlation is observed with the characteristics of blood flow through the left ICA (Table 1).

A

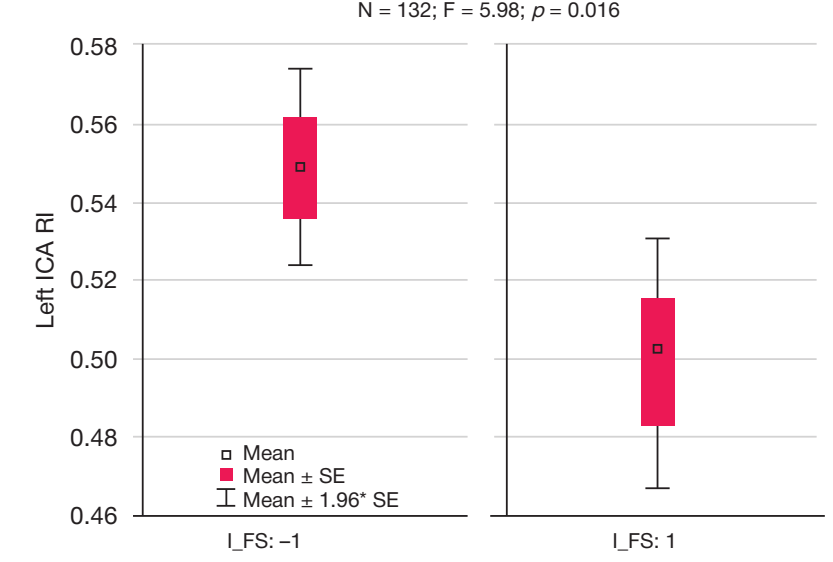

All the correlation coefficients were negative, which meant that the smaller the $\mathrm{Rl}$, the better the cognitive indicators (see Table 1). In men, there was a significant correlation between the left ICA RI and the delayed recall score $(-0.37 ; n=48$; $p=0.009$ ).

Characteristics of the right ICA RI correlated with recognition of nonverbal letter patterns, and the left ICA RI correlated with the characteristics of verbal fluency, immediate recall, and delayed recall.

Fig. 1 demonstrates the correlation of the left ICA RI with some cognitive indicators (verbal fluency and delayed recall) in the mixed-gender group. In both cases, lower RI values, which were closer to the normal physiological values, corresponded to better preserved cognitive functions.

The average verbal fluency in all examined patients was $12.9 \pm 0.31$ words (see Fig. 1A). The average value of this indicator in patients with low verbal fluency (less than 13 words $(-1))$ was $10.0 \pm 0.23$ words $(S D=2.03, n=76)$. In the group with verbal fluency exceeding 13 words (1), the average value of the indicator was $16.2 \pm 0.34$ words (SD $=2.69, n=62$ ).

In a similar fashion, the low and high delayed recall scores were less or more than five words, i.e. the half of the maximum recall score of 10 (see Fig. 1B). In the group with low delayed recall score $(-1)$, the average value was $3.0 \pm 0.19$ words (SD $=1.18, n=40)$. In the group with high delayed recall score (1), the average value was $7.3 \pm 0.44$ words $(S D=1.19, n=77)$.

Thus, the relatively preserved cognitive functions were associated with lower left ICA RI values with a rather high significance level $(p<0.001)$ (Fig. 1B).

$\mathrm{RI}$ values for delayed recall are of prime interest, since in this case it may be said that brain plasticity impairment, associated with poor vocabulary recall scores, starts when RI exceeds 0.55 , i.e. when low delayed recall values are observed. RI values under 0.54 correspond to relatively normal delayed recall scores. Thus, a boundary between relatively normal and altered $\mathrm{RI}$ values is in the range of $0.54-0.55$. It is interesting, because this is consistent with the average $R$ l value of $0.54 \pm 0.013$

The varying degrees of success in realization of cognitive functions depending on the left ICA RI raise the issue of the brain network state under these conditions. All subjects were divided into two groups with $\mathrm{RI}$ values above or below the average (the average values in these groups were $0.42 \pm$ 0.007 and $0.61 \pm 0.010$, respectively). Fig. $2 \mathrm{~A}$ demonstrates that higher indicators of interhemispheric connections in the basal ganglia, insular cortex, and cerebellum constitute the

$\mathrm{B}$

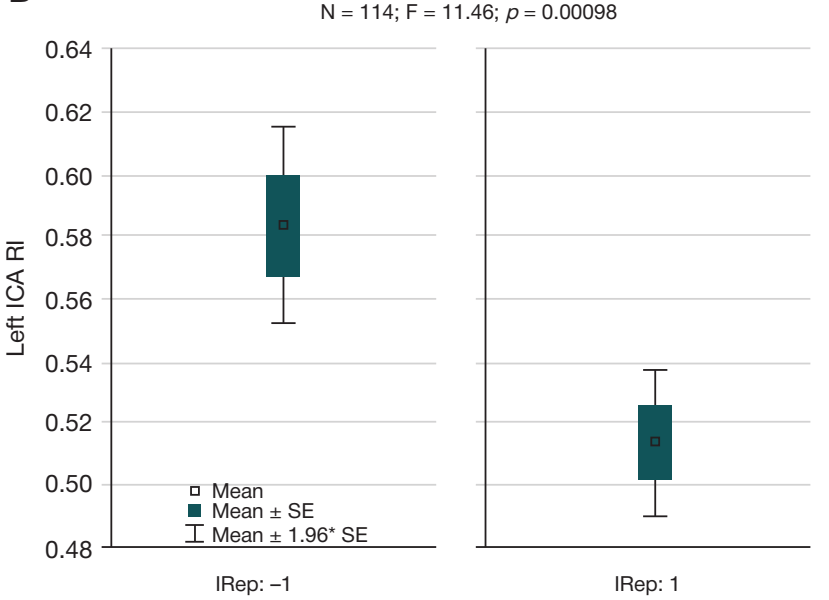

Fig. 1. Left ICA RI in patients with low and high cognitive test scores. A. Left ICA RI in patients with low (-1) and high (1) verbal fluency. B. Left ICA RI in patients with low (-1) and high (1) delayed recall score. I_FS — verbal fluency; IRep — delayed recall; N — number of examined patients; F — F-test; $p$ — significance level; SE — standard error 
A

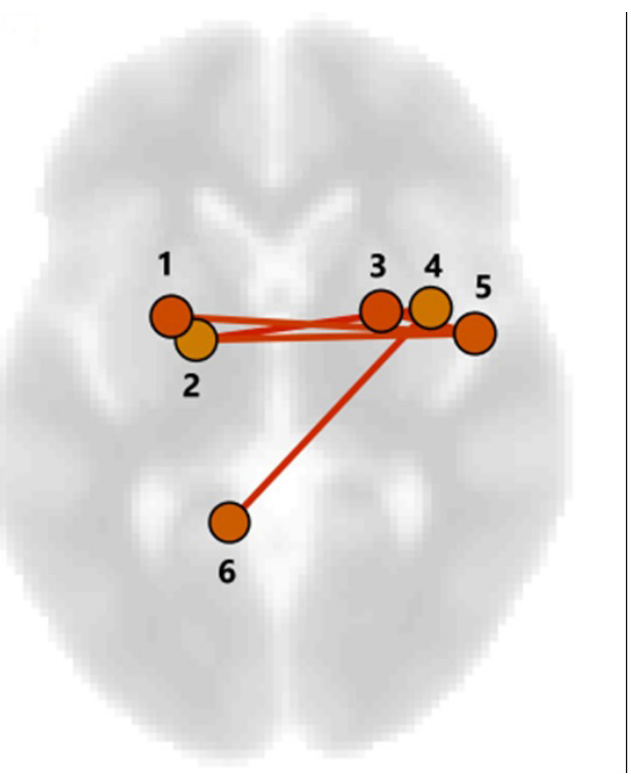

B

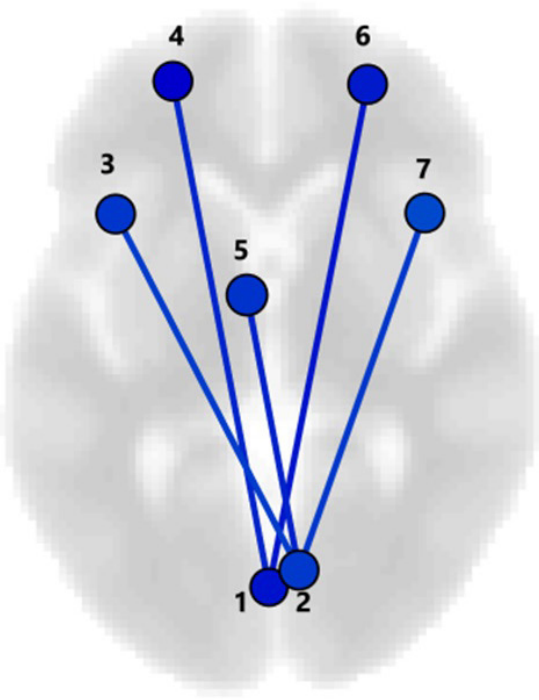

Fig. 2. Differences in connectivity between patients with low $(\mathbf{A})$ and high $(\mathbf{B})$ left ICA RI. A. Connectivity significantly prevailing in patients with low left ICA RI values compared to patients with high RI ( r, I - right and left; 1, 3 - Putamen I, r; 2. - Pallidum; 4 - Insular Cortex (IC); 5 - Planum Polare (PP); 6 - Cerebellum). B. Connectivity significantly prevailing in patients with high left ICA RI values compared to patients with low RI (1 - NetWorks Cerebellar PosteRlor (NW Cereb Post); 2 - SupracalcaRIne Cortex (SCC); 4, 6 - Frontal Pole (FP) I, r; 3, 7 - Frontal Operculum (FO); 5 - Supplementary Motor Cortex (SMC))

main difference between brain networks in patients with normal physiological RI compared to blood flow in patients with more stiff vascular walls (high Rl). The relatively higher connectivity of neuronal networks of the cerebellum and a part of sphenoidal cortex with the frontal regions, comprising frontal pole and motor regions, were observed in patients with higher Rl. The reported effect did not correlate with age, since the group with lower $\mathrm{RI}$ was older (68.8 \pm 1.5 years), and the group with higher $\mathrm{RI}$ was younger $(62.9 \pm 2.1$ years).

The differences were statistically significant at $p=0.025$. However, in the older group, higher indicators of cognitive functions were observed, especially indicators of delayed recall. This could be due to the peculiarities of the sample of a random variable, as well as to the different degree of malignancy of the disease in patients of different age groups, as in other diseases (Alzheimer's disease, etc.).

Statistical parameters of the discussed connections are presented in Table 2.

The data obtained demonstrate that strong interhemispheric connections in the basal ganglia and cerebral cortex are probably the factor associated with preserved cognitive functioning.

\section{DISCUSSION}

The average $\mathrm{Rl}$ values in patients with $\mathrm{CCl}$, registered during our study, were close to the index values, registered in older people of appropriate age. Some authors point out that RI of 0.7 is the upper boundary of the normal range in people of elderly and senile age [16]. Our records show that in patients with $\mathrm{CCl}$ this boundary for the left ICA passes through 0.55 . Regardless of the system of the circle of Willis, blood flow through the left and right ICA has more to do with blood supply of ipsilateral hemisphere than with blood supply of contralateral hemisphere. Therefore, the decreased (primarily due to atherosclerosis) left or right carotid artery blood flow affects various cognitive functions or, according to some authors, verbal and nonverbal intelligence [2]. According to our information, cognitive processes, associated with verbal functions, correlate with the left ICA RI, and those, associated with nonverbal functions, correlate with the right ICA RI.

Mild cognitive impairment is often observed in patients with unilateral stenosis and high ICA RI. However, the functional and structural integrity of brain networks has been reported. Alternatively, the developing cognitive decline is almost always

Table 2. Significant differences in connectivity between patients with low and high left ICA RI values. A. Positive differences. B. Negative differences

\begin{tabular}{|l|c|c|c|}
\hline Connectivity A & T values & $p$ (unadjusted) & $p$ (FDR) \\
\hline PP r-Putamen r & $\mathrm{T}(49)=3.39$ & 0.0007 & 0.0487 \\
\hline PP r-Putamen I & $\mathrm{T}(49)=3.34$ & 0.0008 & 0.0487 \\
\hline PP r-Pallidum I & $\mathrm{T}(49)=3.30$ & 0.0009 & 0.0487 \\
\hline IC r-Pallidum I & $\mathrm{T}(49)=3.65$ & 0.0003 & 0.0388 \\
\hline IC r-Cerebellum9 I & $\mathrm{T}(49)=3.52$ & 0.0005 & 0.0388 \\
\hline Connectivity B & & 0.0003 & 0.0420 \\
\hline SCC r-SMC I & $\mathrm{T}(49)=-3.70$ & 0.0007 & 0.0420 \\
\hline SCC r-FO r & $\mathrm{T}(49)=-3.39$ & 0.0008 & 0.0420 \\
\hline SCC r-FO I & $\mathrm{T}(49)=-3.35$ & 0.0002 & 0.0266 \\
\hline NW Cereb Post-FP r & $\mathrm{T}(49)=-3.86$ & 0.0003 & 0.0266 \\
\hline NW Cereb Post-FP I & $\mathrm{T}(49)=-3.64$ & & \\
\hline
\end{tabular}

Note: $T$ — Student's $t$-test; $p$ (unadjusted) — significance level unadjusted for multiple comparisons; $p$ (FDR) — significance level adjusted for multiple comparisons; FDR - false discovery rate; other keys are provided in the notes to Fig. 2 
accompanied by brain network alterations. Thus, cognitive deficit is an important indicator of the neuronal network rearrangement [4]. The fact, that blood flow through the left and right carotid arteries is strongly associated with blood supply of ipsilateral hemisphere, is important. This means that the decreased blood flow through the left ICA is followed by impaired cognitive, mainly verbal, functions, and the decreased blood flow through the right ICA is often asymptomatic and is seldom related to verbal functions. It is our assessment that structural impairments in neuronal networks, and cognitive decline in the context of abnormal hemodynamics and increased $\mathrm{RI}$ result from the functional decline in various brain structures due to unequal sensitivity of those to oxygen deficiency. This occurs for two reasons: because of different sensitivity of the cortex and subcortical structures to oxygen deficiency, and because of focal and diffuse lesion in brain structures, common to $\mathrm{CCl}$. No MRI-visible foci were found in the studied sample.

However, brain self-regulation, being the principle of brain functioning, is preserved, but the functional system is formed by different neurons. Reorganization of the resting-state brain networks is observed in patients with stenosis in either one or both ICA. This is probably due to subtle white matter integrity disruptions. In general, hemodynamic disorders in one hemisphere, followed by cognitive impairment, often lead to changes in brain natworks, affecting both hemispheres $[2,4]$. That is perfectly understandable, since both hemispheres are involved in realization of any cognitive function, however, parts, played by the right and the left hemisphere, may vary considerably. That is why interhemispheric communication assumes particular importance, which has been confirmed by our findings. This fact has been noted in some other papers. In particular, it has been shown, that reduced default mode network and frontoparietal networks connectivity correlates with lower verbal fluency and delayed recall scores [17].

The sample of patients with $\mathrm{CCl}$, assessed using fMRI, was smaller compared to the sample of patients, assessed using duplex ultrasonography and psychological testing only. Nevertheless, this does not impose any serious restrictions on the interpretation of the results. The sample of subjects assessed using fMRI (55 patients with $\mathrm{CCl}$ ) is to be considered representative: the patients were randomly selected; they did not differ in average RI values and psychological test scores. There is no reason to believe that two discussed above samples could reflect different patterns.

In general, juxtaposing the hemodynamic parameters of the major arteries of the head and the characteristics of fMRI BOLD signals is promising in terms of studying the pathogenesis of vascular diseases.

\section{CONCLUSIONS}

The left ICA resistive index (RI) correlates with preserved cognitive functions in patients with $\mathrm{CCl}$. The left ICA $\mathrm{RI}$ below 0.55-0.54 corresponds to a more successful realization of verbal cognitive functions. Variation of the right ICA RI does not correlate with the characteristics of verbal cognitive functions. The left ICA RI correlates with differences in the organization of the brain networks: low, normal physiological RI values correspond to the better presented interhemispheric connections in the cerebral cortex, basal ganglia, and brainstem. High RI values correspond to higher connectivity between frontal and occipital cortical regions, as well as with cerebellum. In patients with $\mathrm{CCI}$, the left ICA RI can be considered as a biomarker of cognitive decline and brain networks reorganization.

\section{References}

1. Suslina ZA, Illarioshkin SN, Piradov MA. Nevrologija i nejronauki prognoz razvitija. Annaly klinicheskoj i jeksperimental'no nevrologii. 2007; 1 (1): 5-9. Russian.

2. Hideyuki I, Fumiaki O, Satoshi S, et. al. Cognitive outcome differences on the side of carotid artery stenting. I Vasc Surg. 2013; 57 (1): 125-30. DOI: https://doi.org/10.1016/j. jvs.2012.07.043.

3. Rinjani A, Mesiano T, Andini PW, et al. Resistive index of interna carotid artery and common carotid artery in patients with cerebral small vascular disease. J Hypertens. 2021: 39: 16-e17. DOI: 10.1097/01.hjh.0000752596.61984.bf.

4. Avirame K, Lesemann A, List J, Witte AV, Schreiber SJ, Flöel A. Cerebral autoregulation and brain networks in occlusive processes of the internal carotid artery. J Cereb Blood Flow Metab. 2015; 35 (2): 240-7. DOI:10.1038/jcbfm.2014.190.

5. Greicius M. Resting-state functional connectivity in neuropsychiatric disorders. Curr Opin Neurol. 2008; 21: 424-30.

6. Marchi NA, Ramponi C, Hirotsu C, et al. Mean oxygen saturation during sleep is related to specific brain atrophy pattern. Ann Neurol. 2020 Jun; 87 (6): 921-30. DOI: 10.1002/ana.25728. Epub 2020 Apr 20. PMID: 32220084.

7. Ventura-Antunes L, Herculano-Houzel S. Energy supply per neuron is constrained by capillary density in the mouse brain. BioRxiv 2020.02.03.932434. DOI: https://doi. org/10.1101/2020.02.03.932434.

8. Marshall RS, Krakauer JW, Matejovsky T, et al. Hemodynamic impairment as a stimulus for functional brain reorganization. $J$ Cereb Blood Flow Metab. 2006; 26 (10): 1256-62. DOI:10.1038/ sj.jcbfm. 9600274 .

9. Morris JC. Clinical dementia rating: a reliable and valid diagnostic and staging measure for dementia of the Alzheimer type. Int Psychogeriatric. 1997; 9 Suppl 1: 173-6; discussion 177-8. DOl: 10.1017/s1041610297004870. PMID: 9447441.

10. Tanashjan MM, Maksimova MJu, Domashenko MA. Discirkuljatornaja jencefalopatija. Putevoditel' vrachebnyh naznachenii. Terapevticheskij spravochnik. 2015; 2: 1-25. Russian.

11. Batasheva T, Artemova IJu, Vdovichenko TV. Hronicheskaja ishemija mozga: mehanizmy razvitija i sovremennoe kompleksnoe lechenie. Consilium medicum. 2004; 3 (4). Available from: http:// old.consilium-medicum.com/media/refer/04_04/51.shtml. Russian.

12. Zaharov $\mathrm{V}$, Lokshina $A B$. Kognitivnye narushenija pri discirkuljatornoj jencefalopatii. RMZh. 2009; №20: 1325-31. Russian.

13. Lurija AR. Lekcii po obshhej psihologii. SPb.: Piter, 2006; 320 s. Russian.

14. Fokin VF, Shabalina AA, Ponomareva NV, Medvedev RB, Lagoda OV, Tanashjan MM. Soprjazhennost' pokazatelej jenergeticheskogo obmena i urovnja gormona stressa kortizola s kognitivnymi harakteristikami bol'nyh discirkuljatornoj jencefalopatiej. Annaly klinicheskoj i jeksperimental'noj nevrologii. 2018; 4 (12): 47-51. Russian.

15. Whitfield-Gabrieli S, Nieto-Castanon A. Conn: a functional connectivity toolbox for correlated and anticorrelated brain networks. Brain Connect. 2012; 2 (3): 125-41. DOI: 10.1089/ brain.2012.0073.

16. Staub D, Meyerhans A, Bundi B, Schmid HP, Frauchiger B. Prediction of cardiovascular morbidity and mortality: comparison of the internal carotid artery resistive index with the common carotid artery intima-media thickness. Stroke. 2006 Mar; 37 (3): 
800-5. DOI: 10.1161/01.STR.0000202589.47401.c6. Epub 2006 Jan 26. PMID: 16439703.

17. Wang Y, Risacher SL, West JD, McDonald BC, Magee TR,
Farlow MR. Altered default mode network connectivity in older adults with cognitive complaints and amnestic mild cognitive impairment. J Alzheimers Dis. 2013; 35: 751-60.

\section{Литература}

1. Суслина З. А., Иллариошкин С. Н., Пирадов М. А. Неврология и нейронауки - прогноз развития. Анналы клинической и экспериментальной неврологии. 2007; 1 (1): 5-9.

2. Hideyuki I, Fumiaki O, Satoshi S, et. al. Cognitive outcome differences on the side of carotid artery stenting. I Vasc Surg. 2013; 57 (1): 125-30. DOI: https://doi.org/10.1016/j. jvs.2012.07.043

3. Rinjani A, Mesiano T, Andini PW, et al. Resistive index of internal carotid artery and common carotid artery in patients with cerebral small vascular disease. J Hypertens. 2021: 39: 16-e17. DOl: 10.1097/01.hjh.0000752596.61984.bf.

4. Avirame K, Lesemann A, List J, Witte AV, Schreiber SJ, Flöel A. Cerebral autoregulation and brain networks in occlusive processes of the internal carotid artery. J Cereb Blood Flow Metab. 2015; 35 (2): 240-7. DOI:10.1038/jcbfm.2014.190.

5. Greicius M. Resting-state functional connectivity in neuropsychiatric disorders. Curr Opin Neurol. 2008; 21: 424-30.

6. Marchi NA, Ramponi C, Hirotsu C, et al. Mean oxygen saturation during sleep is related to specific brain atrophy pattern. Ann Neurol. 2020 Jun; 87 (6): 921-30. DOI: 10.1002/ana.25728. Epub 2020 Apr 20. PMID: 32220084.

7. Ventura-Antunes L, Herculano-Houzel S. Energy supply per neuron is constrained by capillary density in the mouse brain. BioRxiv 2020.02.03.932434. DOI: https://doi. org/10.1101/2020.02.03.932434.

8. Marshall RS, Krakauer JW, Matejovsky T, et al. Hemodynamic impairment as a stimulus for functional brain reorganization. $J$ Cereb Blood Flow Metab. 2006; 26 (10): 1256-62. DOI:10.1038/ sj.jcbfm. 9600274 .

9. Morris JC. Clinical dementia rating: a reliable and valid diagnostic and staging measure for dementia of the Alzheimer type. In Psychogeriatric. 1997; 9 Suppl 1: 173-6; discussion 177-8. DOI: 10.1017/s1041610297004870. PMID: 9447441.

10. Танашян М. М., Максимова М. Ю., Домашенко М. А. Дисциркуляторная энцесралопатия. Путеводитель врачебных назначений. Терапевтический справочник. 2015; 2: 1-25.

11. Баташева Т. Т., Артемова И. Ю., Вдовиченко Т. В. Хроническая ишемия мозга: механизмы развития и современное комплексное лечение. Consilium medicum. 2004; 3 (4). Available from: http://old.consilium-medicum.com/media/refer/04_04/51. shtml.

12. Захаров В. В., Локшина А. Б. Когнитивные нарушения при дисциркуляторной энцесалопатии. РМЖ. 2009; №20: 132531.

13. Лурия А. Р. Лекции по общей психологии. СПб.: Питер, 2006; $320 \mathrm{c}$.

14. Фокин В. Ф., Шабалина А. А., Пономарева Н. В., Медведев Р. Б., Лагода О. В., Танашян М. М. Сопряженность показателей энергетического обмена и уровня гормона стресса кортизола с когнитивными характеристиками больных дисциркуляторной энцесралопатией. Анналы клинической и экспериментальной неврологии. 2018; 4 (12): 47-51.

15. Whitfield-Gabrieli $S$, Nieto-Castanon A. Conn: a functional connectivity toolbox for correlated and anticorrelated brain networks. Brain Connect. 2012; 2 (3): 125-41. DOI: 10.1089/ brain.2012.0073.

16. Staub D, Meyerhans A, Bundi B, Schmid HP, Frauchiger B. Prediction of cardiovascular morbidity and mortality: comparison of the internal carotid artery resistive index with the common carotid artery intima-media thickness. Stroke. 2006 Mar; 37 (3): 800-5. DOI: 10.1161/01.STR.0000202589.47401.c6. Epub 2006 Jan 26. PMID: 16439703.

17. Wang Y, Risacher SL, West JD, McDonald BC, Magee TR, Farlow MR. Altered default mode network connectivity in older adults with cognitive complaints and amnestic mild cognitive impairment. J Alzheimers Dis. 2013; 35: 751-60. 